\title{
Effect of serial-day exposure to nitrogen dioxide on airway and blood leukocytes and lymphocyte subsets
}

\author{
C. Solomon*,\#, D.L. Christian*, L.L. Chen*,\#, B.S. Welch*, M.T. Kleinman ${ }^{+}$, E. Dunham*, \\ D.J. Erle*,\#, J.R. Balmes*,\#
}

\begin{abstract}
Effect of serial-day exposure to nitrogen dioxide on airway and blood leukocytes and lymphocyte subsets. C. Solomon, D.L. Christian, L.L. Chen, B.S. Welch, M.T. Kleinman, E. Dunham, D.J. Erle, J.R. Balmes. (C) ERS Journals Ltd 2000.

ABSTRACT: Nitrogen dioxide $\left(\mathrm{NO}_{2}\right)$ is a free radical-producing oxidant gas. Inhalation of $\mathrm{NO}_{2}$ could cause airway inflammation, and decrease immune function. This experiment tested the hypothesis that exposure to $\mathrm{NO}_{2}$ would: 1) increase leukocytes in bronchoalveolar lavage (BAL); and 2) change the distribution of lymphocyte subsets and activation in BAL and peripheral blood (PB).

Using a counter-balanced, repeated-measures design, 15 healthy volunteers were exposed to filtered air (FA) or 2.0 parts per million $\mathrm{NO}_{2}$ for $4 \mathrm{~h}^{-\mathrm{day}^{-1}}(4 \times 30 \mathrm{~min}$ of exercise), for three consecutive days. Bronchoscopy was performed $18 \mathrm{~h}$ following each exposure set, and $\mathrm{PB}$ was drawn pre-exposure and pre-bronchoscopy. Flow cytometry was used to enumerate lymphocyte subsets and activation makers in BAL and $\mathrm{PB}$.

In the bronchial fraction, there was an increase in the percentage of neutrophils following $\mathrm{NO}_{2}$ exposure compared to $\mathrm{FA}$ (median (interquartile range): $10.6(4.8-$ $17.2) \%$ versus $5.3(2.5-8.3) \% ; p=0.005)$. In the BAL, there was a decrease in the percentage of T-helper cells following $\mathrm{NO}_{2}$ exposure compared to FA $(55.9(40.8-$ $62.7) \%$ versus $61.6(52.6-65.2) \% ; p=0.022)$. For $P B$, there were no between-condition differences in any leukocyte or lymphocyte subsets, or activation.

In conclusion exposure to nitrogen dioxide results in bronchial inflammation and a minimal change in bronchoalveolar lavage T-helper cells, and no changes in peripheral blood cells.
\end{abstract}

Eur Respir J 2000; 15: 922-928.

\begin{abstract}
*Lung Biology Center and ${ }^{\#}$ Center for Occupational and Environmental Health, University of California, San Francisco, CA, USA. ${ }^{+}$Dept of Community and Environmental Medicine, University of California, Irvine, CA, USA.
\end{abstract}

Correspondence: C. Solomon, Lung Biology Center, Box 0854, University of California, San Francisco, CA. 94143, USA. Fax: 14152064123

Keywords: Inflammation

leukocytes

lymphocytes

nitrogen dioxide

$\mathrm{NO}_{2}$ exposure

Received: May 181999

Accepted after revision January 252000

Supported by California Air Resources Board Contract No. 393-317 and National Center for Research Resources RR0008335 , USA.
Nitrogen dioxide $\left(\mathrm{NO}_{2}\right)$ is a free radical-producing oxidant gas. Atmospheric $\mathrm{NO}_{2}$ is derived from the partial oxidation of nitric oxide, directly from combustion, and indirectly from reactions in ambient air [1]. The primary sources of $\mathrm{NO}_{2}$ in indoor air are gas-burning equipment and tobacco smoke $[2,3]$, and in outdoor air are combustion engine and fossil-fuel burning emissions [4]. The concentration of $\mathrm{NO}_{2}$ can range: up to $0.5-0.6$ parts per million (ppm; 45 min period); $3.0-4.0$ ppm (peak) in indoor air; 0.007-0.065 ppm (48 h mean); and 0.2-0.6 ppm (peak), in outdoor air [2,5-7]. $\mathrm{NO}_{2}$ has low water solubility $\left(0.037 \mathrm{~mL} \cdot \mathrm{mLH}_{2} \mathrm{O}^{-1}\right.$ at $\left.35^{\circ} \mathrm{C}\right)$ [8], therefore a large fraction of inhaled $\mathrm{NO}_{2}$ could be deposited in the peripheral airways. Inhaled $\mathrm{NO}_{2}$, or a component or reaction product of $\mathrm{NO}_{2}$, could subsequently be delivered via tissue absorption and transfer across the blood-gas interface to the blood, therefore, systemic effects are possible.

Some epidemiological data suggest that exposure to ambient $\mathrm{NO}_{2}$ is associated with an increased incidence of respiratory symptoms and illness [9-13]. However, other studies have indicated no association between $\mathrm{NO}_{2}$ exposure and respiratory symptoms or illness [14-16]. A metaanalysis of the data from studies, involving children (age 5-12 yrs), indicated that a long-term increase in $\mathrm{NO}_{2}$ exposure of $0.015 \mathrm{ppm}$ was associated with a $20 \%$ increase in the odds of respiratory illness [17]. No such analysis is available for epidemiological data on adults.

Due to its cytotoxicity, inhalation of $\mathrm{NO}_{2}$ can induce airway inflammation and change the leukocyte distribution in the airway lining fluid. Controlled single exposures of healthy individuals to $2.25,3.5,4.0$, and $5.5 \mathrm{ppm} \mathrm{NO}_{2}$ for $20 \mathrm{~min}$, or $2.0 \mathrm{ppm} \mathrm{NO}$ for 4 or $6 \mathrm{~h}$ have increased the number and percentage of neutrophils, decreased the percentage of macrophages in the bronchial fraction (BFx), increased the number of lymphocytes and mast cells, and decreased the number of macrophages in the bronchoalveolar lavage (BAL) at $4,6,8,18$, or $24 \mathrm{~h}$ post-exposure, compared to pre-exposure [18-22]. Controlled multipleday exposures to $0.60 \mathrm{ppm} \mathrm{NO}_{2}$ for $2 \mathrm{~h}$ on 4 out of 6 days, $1.5 \mathrm{ppm}$ or $4.0 \mathrm{ppm} \mathrm{NO}_{2}$ for 20 min every alternate day for 6 exposures did not change the percentage of macrophages, neutrophils, lymphocytes, or mast cells in either the BFx or BAL at 2 or $24 \mathrm{~h}$ post-exposure [23-25]. However, exposure to $4.0 \mathrm{ppm} \mathrm{NO}_{2}$ for 20 min every alternate day for six exposures, or $2.0 \mathrm{ppm} \mathrm{NO}_{2}$ for $4 \mathrm{~h}$ for 4 days, decreased the percentage of mast cells, and increased the percentage of neutrophils in the BFx 1.5 or $24 \mathrm{~h}$ postexposure $[25,26]$.

Cellular immunity involves subsets of lymphocytes; Tcells, B-cells, and natural killer (NK) cells, which are 
differentiated on the basis of surface-antigen cluster designations (CD). Lymphocytes become activated when stimulated by a specific antigen or nonspecific mitogens, resulting in cellular proliferation and differentiation. When activated, T-cells express specific surface proteins at higher levels; CD69 and CD25 are early and intermediate timeframe activation makers, respectively [27-29]. An $\mathrm{NO}_{2-}$ induced decrease in lymphocyte viability or activation could decrease immune function. Controlled single exposures to $3.5 \mathrm{ppm} \mathrm{NO}_{2}$ for $20 \mathrm{~min}$, or $2.0 \mathrm{ppm} \mathrm{NO}$ for $4 \mathrm{~h}$ have increased the number of T-cells, B-cells, NK cells, and CD69+ T-cells in BAL at 6 or $24 \mathrm{~h}$ post-exposure [20, 21]. However, multiple-day exposures to $0.60 \mathrm{ppm} \mathrm{NO}_{2}$ for $2 \mathrm{~h}$ on 4 of 6 days, or 1.5 or $4.0 \mathrm{ppm} \mathrm{NO}_{2}$ on alternate days for 6 exposures, have decreased the percentage of Tsuppressor cells and increased the T-suppressor/T-helper cell ratio, number of B-cells, and increased and decreased the number of NK cells [23-25]. Single and multiple day exposures to $\mathrm{NO}_{2}$ have decreased the total lymphocyte number, as well as T-suppressor cells and CD4-CD8- Tcells in blood [21, 24, 25].

Due to free-radical activity, oxidation, and the formation of nitric and nitrous acid, $\mathrm{NO}_{2}$ can affect cell function and viability by damaging lipids, proteins, and other biomolecules [30]. Exposure to $\mathrm{NO}_{2}$ over a range of concentrations and durations has decreased total protein and albumin, the functional capacity of alpha-1-protease inhibitor, uric and ascorbic acids, and alveolar permeability, and has increased alpha-2-macroglobulin, in BFx and BAL [21, 26, 31-34].

Cumulatively, the reviewed data indicate that, for the exposure designs used, there are differences in the cellular response to multiple-day, compared to single-day $\mathrm{NO}_{2}$ exposure, and that there is some degree of redistribution of lymphocyte subsets and activation following $\mathrm{NO}_{2}$ exposure. There also appears to be a difference in the bronchial and bronchoalveolar regional cellular and protein responses to inhaled $\mathrm{NO}_{2}$. This study was designed to test the hypothesis that serial-day exposure to $2.0 \mathrm{ppm} \mathrm{NO}_{2}$ would change the distribution of leukocytes and lymphocyte subsets and activation of lymphocytes in BAL.

\section{Methods}

\section{Design}

This experiment used a repeated-measures, counterbalanced, single-blind design. Each subject was exposed, during separate exposure periods, to a control condition of filtered air (FA) and to $2.0 \mathrm{ppm} \mathrm{NO}_{2}$ in FA. Subjects were unaware of the exposure condition. The exposure periods were for $4 \mathrm{~h}$ per day for three consecutive days. Total and differential cell counts, lymphocyte subset counts and activation, and total protein and lactate dehydrogenase (LDH) were measured in BAL post-exposure. Lymphocyte subset counts and activation were also measured in peripheral blood (PB) pre- and post-exposure. A minimum of 3 weeks separated the two exposure condition periods.

\section{Subjects}

The subject group consisted of 15 healthy volunteers who were characterized by physical characteristics, spirometric pulmonary function, specific airway resistance and nonspecific airway responsiveness (table 1). All subjects completed a medical history questionnaire, denied a history of pulmonary dysfunction, were nonsmokers, and had no respiratory tract illness in the 3 weeks preceding, or during, the experiment. Subjects abstained from strenuous exercise for $12 \mathrm{~h}$ and caffeine for $4 \mathrm{~h}$ prior to each session. Each subject was informed of the risks of the experiment and provided informed consent prior to participation. The procedures for this experiment were approved by the University of California, San Francisco Committee on Human Research (USA).

\section{Equipment and measurements}

Spirometric pulmonary function, specific airway resistance, and nonspecific airway responsiveness. Forced expired spirometry for the determination of forced vital capacity and forced expiratory volume in one second (FEV1) was performed using a dry-rolling-seal spirometer (Model No. S400; Anderson Instruments, Spirotech Division, Atlanta, GA, USA) using standardized procedures [35]. Specific airway resistance was calculated as the product of total airway resistance and thoracic gas volume, which were both measured using a constant-volume body plethysmograph (Warren E. Collins, Braintree, MA, USA). Airway responsiveness was determined by the FEV1 response to inhalation of nebulized (Model No. 646; Devilbiss, Somerset, PA, USA) phosphate-buffered saline (PBS) followed by increasing doses $(0.26,1.53,4.09,10.48$ $4 \mathrm{~mol})$ of methacholine in PBS delivered via a dosimeter (Rosenthal, Louisville, CO, USA) at the rate of $0.01 \mathrm{~mL}$. breath $^{-1}[36]$. The airway responsiveness value was taken as either the cumulative dose of methacholine that produced a $20 \%$ decrease in FEV1 from baseline (log-linear interpolation) or, when FEV1 did not decrease by $20 \%$, as the maximum dose of $10.48 \mu \mathrm{mol}$.

Exposure chamber and atmospheric monitoring. The exposure sessions were performed in a custom built steel and glass exposure chamber (Model No. W00327-3R; NorLake Inc., Hudson, WI, USA), $2.5 \times 2.5 \times 2.4 \mathrm{~m}$ in size, with an average airflow rate of $92 \mathrm{~m}^{3} \cdot \mathrm{min}^{-1}$. The chamber air supply was sourced from ambient air that was filtered by passing through purifying (Model No. 6239; Purafil, Atlanta, GA, USA) and high efficiency particle (HEPA; EcoAir, San Diego, CA, USA) filters. The filtered air was dehumidified by passing through a drier (Model No. HC575; Cargocaire Engineering Corp., Amesbury, MA, USA). Subsequently, the air temperature was decreased with a chilled-water coil, and the humidity increased with steam (Model No. NHMC-050; Nortec, Ogdensbury, NY, USA), to obtain the preset temperature $\left(20.0^{\circ} \mathrm{C}\right)$ and relative humidity $(50 \%)$ conditions in the chamber. The temper-ature and relative humidity inside the chamber were monitored (3 min intervals) and controlled throughout the exposures (table 2: Model No. DSC 8500; Johnson Controls, Poteau, $\mathrm{OK}, \mathrm{USA}$ ). For the $\mathrm{NO}_{2}$ exposures, $\mathrm{NO}_{2}$ was supplied from gas cylinders containing 250-500 ppm $\mathrm{NO}_{2}$ in air (Liquid Carbonic Corp., Oakbrook, IL, USA) which was piped through teflon tubing directly into the intake duct of the chamber. The $\mathrm{NO}_{2}$ concentration in the chamber was monitored continuously ( $30 \mathrm{~s}$ intervals) throughout the exposures (table 2), chamber air being piped through teflon tubing directly to a chemiluminescent oxides of nitrogen $\left(\mathrm{NO}_{\mathrm{x}}\right.$ ) analyser (Model No. 8840; Monitor Labs Inc., Englewood, $\mathrm{CO}$, USA). The $\mathrm{NO}_{\mathrm{x}}$ analyser was 
Table 1. - Individual subjects physical, spirometric lung function and airway responsiveness characteristics

\begin{tabular}{|c|c|c|c|c|c|c|c|c|c|}
\hline Subject & Sex & $\begin{array}{l}\text { Age } \\
\text { yrs }\end{array}$ & $\begin{array}{l}\text { Height } \\
\mathrm{cm}\end{array}$ & $\begin{array}{c}\text { Mass } \\
\mathrm{kg}\end{array}$ & $\begin{array}{c}\text { FVC } \\
\text { L }\end{array}$ & $\begin{array}{c}\text { FEV1 } \\
\text { L }\end{array}$ & $\begin{array}{c}\text { FEV } 1 / \mathrm{FVC} \\
\%\end{array}$ & $\begin{array}{c}\mathrm{SRaw} \mathrm{L} \times \\
\mathrm{cmH}_{2} \mathrm{O} \cdot \mathrm{L}^{-1} \cdot \mathrm{s}^{-1}\end{array}$ & $\begin{array}{l}\text { PD20 } \\
\mu \mathrm{mol}\end{array}$ \\
\hline 1 & M & 25 & 176 & 63.6 & 6.20 & 4.97 & 80 & 3.7 & 10.48 \\
\hline 2 & M & 40 & 177 & 78.2 & 5.02 & 4.23 & 84 & 3.0 & 10.48 \\
\hline 3 & $\mathrm{~F}$ & 32 & 175 & 78.2 & 4.02 & 3.43 & 85 & 2.6 & 10.48 \\
\hline 4 & M & 24 & 189 & 94.1 & 6.93 & 5.60 & 81 & 3.7 & 10.48 \\
\hline 5 & M & 33 & 178 & 77.7 & 7.36 & 5.42 & 74 & 4.2 & 6.01 \\
\hline 6 & $\mathrm{M}$ & 33 & 171 & 88.6 & 4.93 & 4.26 & 87 & 0.75 & 10.48 \\
\hline 7 & M & 26 & 177 & 77.3 & 5.56 & 4.28 & 77 & 3.6 & 4.09 \\
\hline 8 & $\mathrm{~F}$ & 26 & 169 & 66.8 & 4.21 & 3.15 & 75 & 4.8 & 7.29 \\
\hline 9 & $\mathrm{~F}$ & 34 & 163 & 65.0 & 3.74 & 3.43 & 92 & 2.1 & 10.48 \\
\hline 10 & $\mathrm{M}$ & 25 & 173 & 68.2 & 5.63 & 4.55 & 81 & 2.3 & 10.48 \\
\hline 11 & M & 33 & 174 & 68.2 & 5.58 & 4.36 & 78 & 3.4 & 10.48 \\
\hline 12 & $\mathrm{~F}$ & 31 & 165 & 72.7 & 4.32 & 3.42 & 79 & 4.6 & 0.90 \\
\hline 13 & M & 23 & 180 & 79.5 & 5.80 & 5.24 & 87 & 1.9 & 10.48 \\
\hline 14 & M & 28 & 179 & 72.3 & 5.76 & 4.31 & 75 & 6.0 & 10.48 \\
\hline 15 & $\mathrm{M}$ & 26 & 185 & 80.9 & 5.89 & 5.04 & 86 & 2.5 & 10.48 \\
\hline Mean \pm SD & & $29.3 \pm 4.8$ & $175.4 \pm 6.8$ & $75.4 \pm 8.6$ & $5.40 \pm 1.04$ & $4.38 \pm 0.78$ & $81.4 \pm 5.3$ & $3.3 \pm 1.3$ & $8.90 \pm 2.99$ \\
\hline
\end{tabular}

Forced vital capacity (FVC), forced expiratory volume in one second (FEV1), FEV1/FVC \%, specific airway resistance (SRaw) and provocative (cumulative) dose of methacholine causing a 20\% fall in FEV1 (PD20) data are individual means of pre-exposure data for the filtered air and nitrogen dioxide conditions. M: male; F: female.

calibrated using a dynacalibrator (Model No. 340; Valco Instruments; Metronics, Huston, TX, USA) using ultrapure air $\left(\mathrm{NO}_{\mathrm{x}}<0.001 \mathrm{ppm}\right)$ and $\mathrm{NO}_{2}$ of known concentration.

Exercise and pulmonary ventilation. During each exposure, exercise was utilized to induce mouth breathing and to increase minute ventilation $\left(V^{\prime} \mathrm{E}\right)$. The exercise consisted of either walking/running on a treadmill (Model No. M9.1; Precor, Bothel, WA, USA) or pedalling a cycle-ergometer (Model No. 90818e; Monark, Varberg, Sweden). The exercise intensity was adjusted for each subject to a target expired $V^{\prime} \mathrm{E}$ of $25 \mathrm{~L} \cdot \mathrm{min}^{-1} \cdot \mathrm{m}^{-2}$ body surface area. During exercise, $V^{\prime} \mathrm{E}$ was calculated from tidal volume and breathing frequency measured using a pneumotachograph (Model No. 3; Fleisch; Rudolph Inst., Kansas City, MO, USA) at the 10 and $20 \mathrm{~min}$ interval of each $30 \mathrm{~min}$ exercise period. There was no significant difference in the mean $V^{\prime} \mathrm{E}$ between the FA and $\mathrm{NO}_{2}$ conditions (mean \pm SD; 47.8 \pm 5.6 $\mathrm{L} \cdot \mathrm{min}^{-1}$ versus $\left.47.5 \pm 4.8 \mathrm{~L} \cdot \mathrm{min}^{-1} ; \mathrm{p}=0.80\right)$.

Bronchoalveolar lavage and peripheral blood. The bronchoscopies were performed in a dedicated room at San Francisco General Hospital (CA, USA). Vital signs were measured pre- and post-bronchoscopy. Throughout the procedure, intravenous access was maintained, and arterial haemoglobin:oxygen $\left(\mathrm{O}_{2}\right)$ percentage saturation (Model No. Biox 3700; Ohmeda, Madison, WI, USA) and the electrocardiograph (Model No. SM-1; Physiocontrol, Redwood, IA, USA) were monitored. Atropine, to decrease airway secretions, and if required, midazolam, to maintain

Table 2. - Exposure atmospheric characteristics

\begin{tabular}{lcc}
\hline & \multicolumn{2}{c}{ Exposure condition } \\
\cline { 2 - 3 } & $\mathrm{FA}$ & $\mathrm{NO}_{2}$ \\
\hline $\mathrm{NO}_{2}$ ppm & - & $1.95 \pm 0.14$ \\
Temperature ${ }^{\circ} \mathrm{C}$ & $19.9 \pm 0.1$ & $20.2 \pm 0.4$ \\
Relative humidity \% & $50.0 \pm 7.3$ & $56.4 \pm 6.6$ \\
\hline
\end{tabular}

Values are mean \pm SD. FA: filtered air; $\mathrm{NO}_{2}$ : nitrogen dioxide. subject comfort, were administered intravenously. The posterior pharynx was anaesthetized using a $4 \%$ lignocaine gargle, a 1\% lignocaine spray, and 4\% lignocaine-soaked, cottontipped pledgets applied to the mucosa over the ninth cranial nerve. Supplemental $\mathrm{O}_{2}$ was delivered via a nasal canula at $2 \mathrm{~L} \cdot \mathrm{min}^{-1}$. The bronchoscope (Model No. FB 18x; Pentax, Orangeburg, NY, USA), tipped with lignocaine jelly, was introduced through the mouth, and the larynx and airways were anaesthetized using $1 \%$ lignocaine solution as required. The bronchoscope was initially directed and wedged into the right middle lobe orifice $(3 \times 50 \mathrm{~mL}$ lavage), and subsequently the lingula $(1 \times 50 \mathrm{~mL}$ lavage $)$. The purpose of the lingular lavage was to obtain alveolar macrophages for functional assays which will be the subject of another report. The lavages were performed using $0.9 \%$ saline heated to $37^{\circ} \mathrm{C}$. The first $15 \mathrm{~mL}$ of lavage fluid returned was designated the BFx.

Cell enumeration. All lavage samples were immediately placed on ice following collection. A $1 \mathrm{~mL}$ aliquot was removed for the total and differential cell counts. For the BAL and BFx fluids, total cell counts were performed using a haemocytometer (Hausser Scientific, Horsham, PA, USA), and differential cell counts were performed from cytospins subsequently stained (Diff-Quik; Baxter, San Juan, Puerto Rico). Total and differential (400 cells) cell counts were performed in duplicate by two counters. Total and differential cell counts in PB were performed by a certified commercial laboratory (PathLab, San Francisco, CA, USA).

In both the BAL and $\mathrm{PB}$, three colour flow cytometry was used to enumerate lymphocyte subsets on the basis of CD as follows: B-cells (CD19+), T-cells (CD3+), T-helper cells (CD3+ CD4+), T-suppressor cells (CD3+ CD8+), and NK cells (CD3- CD16+ CD56+); and to examine the expression of the activation markers CD25 and CD69 on Tand NK cells. A $100 \mathrm{uL}$ aliquot of either resuspended BAL cells $\left(1 \times 10^{6} \mathrm{~mL}\right.$ in PBS $)$ or anticoagulated whole blood, were stained with saturating concentrations of anti-human leukocyte monoclonal antibodies (Caltag, Burlingame, CA, USA) for $30 \mathrm{~min}$ in the dark at $4{ }^{\circ} \mathrm{C}$. The cells were then washed using PBS, and erythrocytes were lysed (Coulter 
lysis solution, San Francisco, CA, USA). Leukocytes were fixed using $500 \mathrm{~mL}$ of $1 \%$ paraformaldehyde for $5 \mathrm{~min}$ at $21^{\circ} \mathrm{C}$, washed again with PBS, and stored in the dark at $4^{\circ} \mathrm{C}$. Cells were analysed using a FACSort flow cytometer (Becton-Dickinson, San Jose, CA, USA) and CELLQuest software (San Jose, CA, USA). The proportion of lymphocytes that were T-cells was determined by measuring the ratio of T-cells to all lymphocytes (CD13- CD14- CD45 high). The ratio of T-cells to other subsets was determined by calculating the ratio of T-cells to B-cells, NK cells, Thelper cells and T-suppressor cells from samples stained in parallel with appropriate antibody combinations.

Biochemical assays. The BFx and BAL fluids were centrifuged to remove cells and debris; $1 \mathrm{~mL}$ aliquots of each fluid were removed for the LDH measurement; and the remaining supernatants were frozen at $-80^{\circ} \mathrm{C}$. The $\mathrm{LDH}$ assay was performed within $30 \mathrm{~min}$ of the lavage using a commercial kit (Sigma, St Louis, MO, USA) and a spectrophotometer (Model No. DU 65; Beckman, Fullerton, CA, USA). Total protein was measured in the previously frozen aliquots using the modified Lowry assay [37].

\section{Procedure}

Each subject completed nine laboratory sessions. Session 1 was for screening and characterization, subjects performing all pulmonary and airway function tests. Sessions 2-4 were the first exposure condition $\left(\mathrm{FA}\right.$ or $\left.\mathrm{NO}_{2}\right)$ period, and session 5 was for bronchoscopy, which was performed $18 \pm 1 \mathrm{~h}$ following the end of session 4 . Following the minimum 3 week inter-condition period, sessions 6-8 were performed for the other exposure condition (FA or $\mathrm{NO}_{2}$ ), and session 9 was for the bronchoscopy. Each exposure condition period consisted of 4-h exposures performed at the same time on three consecutive days. For each of the exposure sessions, pulmonary function tests were performed immediately pre- and post-exposure, and peak flow was monitored during the exposure at the end of each exercise period. During the exposure sessions, subjects alternated 30-min periods of rest and exercise. PB were collected from a forearm vein using standard procedures. Following the bronchoscopy sessions, subjects were transferred to the General Clinical Research Center (San Francisco General Hospital, CA, USA), where they were observed and released when recovered.

\section{Statistical analyses}

Most of the cell count and biochemical data were not normally distributed. Therefore, all BFx, BAL, and PB between-condition (FA versus $\mathrm{NO}_{2}$ ) comparisons were performed using the Wilcoxon Signed Rank Test. For the PB data, the pre- to post-exposure change within each condition was used for comparisons between the two conditions. Statistical significance was set at $\mathrm{p}<0.05$.

\section{Results}

\section{Bronchoalveolar lavage}

The volumes of lavage fluid returned in the FA and $\mathrm{NO}_{2}$ conditions for the BFx were: median (interquartile range) 15.0 (14.4-15.0) $\mathrm{mL}$ and $15.0(14.7-15.3) \mathrm{mL}$, respecti- vely and for the BAL were $75.0(63.8-83.0) \mathrm{mL}$ and 63.6 (51.0-77.4) $\mathrm{mL}$, respectively.

\section{Total and differential leukocytes}

All differential cell counts for the BFx, BAL, and PB were expressed as a percentage of total leukocytes. In both the BFx and BAL, there was no significant difference in the total leukocyte count between the FA and $\mathrm{NO}_{2}$ conditions (table 3 ). In the $\mathrm{BFx}$, there was a significant increase in the percentage of neutrophils after $\mathrm{NO}_{2}$ exposure as compared to FA (table 3, fig. 1). In the BFx and BAL, there were no other significant differences in the total number or percentage of leukocytes, or the percentage of neutrophils, macrophages, eosinophils, or lymphocytes between the two conditions (table 3 ). In the PB, there was no significant difference in the percentage of monocytes, neutrophils, lymphocytes, or eosinophils between the FA and $\mathrm{NO}_{2}$ conditions (all data within normal range; not shown).

\section{Lymphocyte subsets and activation}

In the BAL, there was a significant decrease in the percentage of T-helper cells after $\mathrm{NO}_{2}$ exposure, as compared to FA (table 4). In the BAL, there were no significant differences in B-cells, T-suppressor cells, and NK cells, between the two conditions (table 4). There were also no

Table 3. - Leukocytes in bronchial fraction (BFx) and bronchoalveolar lavage (BAL), post-exposure to filtered air (FA) and nitrogen dioxide $\left(\mathrm{NO}_{2}\right)$

\begin{tabular}{|c|c|c|c|c|}
\hline \multirow[b]{2}{*}{ Cell } & \multicolumn{2}{|c|}{$\mathrm{BFx}$} & \multicolumn{2}{|c|}{ BAL } \\
\hline & FA & $\mathrm{NO}_{2}$ & FA & $\mathrm{NO}_{2}$ \\
\hline \multicolumn{5}{|l|}{ Leukocytes } \\
\hline$\times 10^{4} \mathrm{~mL}$ & 16.3 & 17.0 & 13.8 & 15.8 \\
\hline IQR & $8.0-19.3$ & $10.3-22.5$ & $8.0-17.5$ & $12.3-20.3$ \\
\hline $95 \%$ CI & $11.2-18.3$ & $12.8-21.2$ & $11.5-21.1$ & $12.8-24.6$ \\
\hline \multicolumn{5}{|l|}{ Leukocytes } \\
\hline$\%$ & 88.8 & 91.7 & 96.3 & 92.3 \\
\hline IQR & 78.1-93.1 & $86.6-95.1$ & $94.0-98.3$ & $88.5-97.0$ \\
\hline $95 \% \mathrm{CI}$ & $80.0-91.4$ & $90.3-95.2$ & $92.3-97.6$ & $85.6-95.9$ \\
\hline \multicolumn{5}{|l|}{ Macrophages } \\
\hline$\%$ & 88.6 & 77.1 & 92.2 & 90.2 \\
\hline IQR & $79.5-92.0$ & $73.8-91.1$ & $86.3-95.3$ & $88.9-91.4$ \\
\hline $95 \%$ CI & $81.4-91.1$ & $72.0-87.1$ & $85.7-94.6$ & $80.3-92.9$ \\
\hline \multicolumn{5}{|l|}{ Neutrophils } \\
\hline$\%$ & 5.3 & $10.6^{*}$ & 2.4 & 3 \\
\hline IQR & $2.5-8.3$ & $4.8-17.2$ & $1.0-4.4$ & $1.4-4.5$ \\
\hline $95 \%$ CI & $3.7-8.3$ & $6.7-20.1$ & $1.6-3.8$ & $1.7-7.0$ \\
\hline \multicolumn{5}{|l|}{ Lymphocytes } \\
\hline$\%$ & 4.3 & 3.6 & 3.1 & 5.8 \\
\hline IQR & $1.8-8.2$ & $2.4-7.9$ & $1.8-6.6$ & $3.9-7.4$ \\
\hline $95 \%$ CI & $2.8-8.3$ & $3.3-6.8$ & $2.2-8.2$ & $3.5-10.5$ \\
\hline \multicolumn{5}{|l|}{ Eosinophils } \\
\hline$\%$ & 0.3 & 1.1 & 0.5 & 0.6 \\
\hline IQR & $0.0-1.8$ & $0.0-1.8$ & $0.0-1.0$ & $0.0-1.9$ \\
\hline $95 \%$ CI & $-1.0-5.2$ & $0.0-4.0$ & $-0.1-4.7$ & $-0.3-4.4$ \\
\hline
\end{tabular}

Values are median and interquartile range (IQR). Leukocytes: percentage of total cells; all others: percentage of leukocytes. 95\% CI: $95 \%$ confidence interval. *: significantly different from filtered air $(\mathrm{p}=0.005)$. 


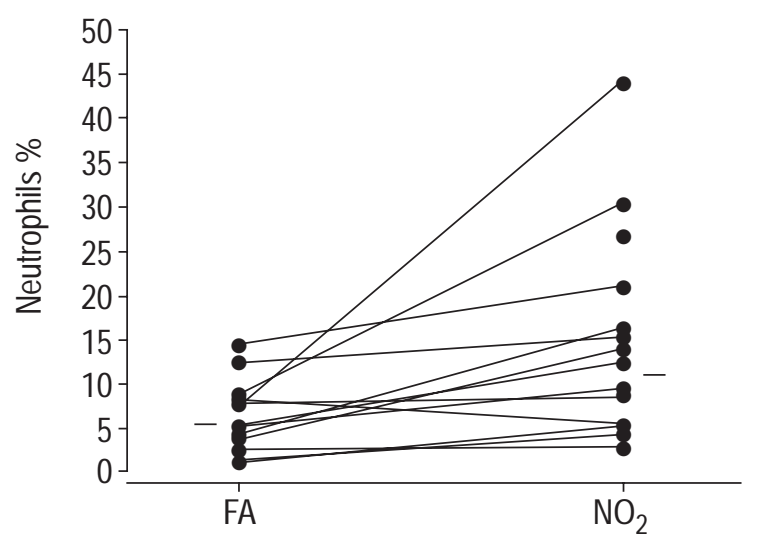

Fig. 1. - Individual (O) and median (horizontal bars) percentage differential neutrophil counts post-exposure to filtered air and nitrogen dioxide $\left(\mathrm{NO}_{2}\right)$.

significant differences for either of the two cell activation markers CD25 and CD69 on T-cells between the two conditions (table 4). In the PB, there were no significant differences in any of the lymphocyte subsets, or in activation of T- or NK cells, between the $\mathrm{FA}$ and $\mathrm{NO}_{2}$ conditions (all data within normal range; not shown).

\section{Total protein and lactate dehydrogenase}

In the $\mathrm{BFx}$, there was a significant decrease in total protein after $\mathrm{NO}_{2}$ exposure as compared to FA (table 5). In the BAL, there was no difference in total protein between the exposure conditions. In both the BFx and BAL, there was no difference in LDH between the two conditions (table 5).

\section{Discussion}

The results of this experiment demonstrate that exposure to $2.0 \mathrm{ppm} \mathrm{NO}_{2}$ for $4 \mathrm{~h}$ per day on three consecutive days produces an increase in neutrophils in the BFx and a decrease in T-helper cells in the BAL. These results indicate that this level of $\mathrm{NO}_{2}$ exposure can induce mild bronchial airway inflammation and a minimal change in one lymphocyte subset involved in cellular immunity.

An increase in the number and percentage of neutrophils in the $\mathrm{BFx}$ has also been found following a single $\mathrm{NO}_{2}$ exposure $[20,21]$. Following other multiple-day exposures, the number or percentage of neutrophils was not changed, or the percentage of neutrophils was increased [23-26]. The total dose of $\mathrm{NO}_{2}$ was lower in the experiments finding no change in neutrophils, compared to the experiment finding an increase in the percent of neutrophils and the current experiment. Therefore, the $\mathrm{NO}_{2}$-induced increase in bronchial neutrophils could be a function of the total dose of $\mathrm{NO}_{2}$, as opposed to the exposure format. The $\mathrm{NO}_{2}$-induced increase in neutrophils in the BFx was not found in the BAL, suggesting a regional difference in $\mathrm{NO}_{2}$ exposure (delivery), absorbance, clearance, or antioxidant defenses.

Single-day exposure to $\mathrm{NO}_{2}$ increases lymphocyte and/ or decreases macrophage counts [18-21]. There were no changes in the percentage of macrophages or lympho-
Table 4. - Lymphocyte subsets and activation in bronchoalveolar lavage, post-exposure to filtered air (FA) and nitrogen dioxide $\left(\mathrm{NO}_{2}\right)$

\begin{tabular}{|c|c|c|}
\hline Cell & FA & $\mathrm{NO}_{2}$ \\
\hline \multicolumn{3}{|c|}{ CD3+ T-cells } \\
\hline$\%$ & 93.3 & 93.8 \\
\hline IQR & $90.1-95.7$ & $90.9-96.2$ \\
\hline $95 \%$ CI & $90.7-94.8$ & $91.8-95.2$ \\
\hline \multicolumn{3}{|c|}{ CD4+ T-cells } \\
\hline$\%$ & 61.6 & $55.9^{*}$ \\
\hline IQR & $52.6-65.2$ & $40.8-62.7$ \\
\hline $95 \%$ CI & $54.7-68.1$ & $46.0-60.4$ \\
\hline \multicolumn{3}{|c|}{ CD8+ T-cells } \\
\hline$\%$ & 28.9 & 31.8 \\
\hline IQR & $18.3-34.7$ & $20.5-50.3$ \\
\hline $95 \% \mathrm{CI}$ & $21.4-32.6$ & $23.1-40.7$ \\
\hline \multicolumn{3}{|c|}{ CD4+/CD8+ T-cells } \\
\hline ratio & 2.3 & 1.7 \\
\hline IQR & $1.5-3.2$ & $0.8-3.2$ \\
\hline $95 \%$ CI & $1.9-3.8$ & $1.2-4.3$ \\
\hline \multicolumn{3}{|c|}{ CD19+ B-cells } \\
\hline$\%$ & 1.3 & 1.3 \\
\hline IQR & $0.8-1.9$ & $0.4-2.0$ \\
\hline $95 \% \mathrm{CI}$ & $0.9-2.2$ & $0.7-1.9$ \\
\hline \multicolumn{3}{|c|}{ CD3- CD16+ CD56+ NK-cells } \\
\hline$\%$ & 0.3 & 0.2 \\
\hline IQR & $0.2-0.9$ & $0.1-0.4$ \\
\hline $95 \% \mathrm{CI}$ & $0.3-0.8$ & $0.2-0.4$ \\
\hline \multicolumn{3}{|c|}{ CD25+ CD4+ T-cells } \\
\hline$\%$ & 30.6 & 30.7 \\
\hline IQR & $18.6-34.2$ & $22.6-36.3$ \\
\hline $95 \% \mathrm{CI}$ & $22.1-32.6$ & $23.7-35.4$ \\
\hline \multicolumn{3}{|c|}{ CD25+ CD8+ T-cells } \\
\hline$\%$ & 7.5 & 8.9 \\
\hline IQR & $5.8-9.6$ & $6.0-13.9$ \\
\hline $95 \% \mathrm{CI}$ & $5.9-9.7$ & $7.2-12.0$ \\
\hline \multicolumn{3}{|c|}{ CD69+ CD4+ T-cells } \\
\hline$\%$ & 71.5 & 68.5 \\
\hline IQR & $61.8-79.1$ & $61.0-76.0$ \\
\hline $95 \% \mathrm{CI}$ & $65.0-76.2$ & $63.1-75.0$ \\
\hline \multicolumn{3}{|c|}{ CD69+ CD8+ T-cells } \\
\hline$\%$ & 78.9 & 81.5 \\
\hline IQR & $73.4-87.5$ & $70.6-89.9$ \\
\hline $95 \%$ CI & $73.3-84.1$ & $75.9-86.7$ \\
\hline
\end{tabular}

Values are median and interquartile range (IQR). Data for CD25+ and CD69+ subsets are percentages of CD4+ T-cell and CD8+ T-cell subsets. 95\% CI: 95\% confidence intervals; NK: natural killer; *: significantly different from filtered air $(\mathrm{p}=0.022)$.

cytes in either the BFx or BAL in the current serial-day exposure experiment. Similarly, other multiple-day exposures did not change lymphocyte or macrophage numbers [23-26]. Hence, the leukocyte distribution response following single-day exposures could be decreased following multiple-day exposures. This difference may be due to an increase in the clearance of $\mathrm{NO}_{2}$ from the airway epithelium or upregulation of antioxidant defenses.

The decrease in T-helper cells after $\mathrm{NO}_{2}$ exposure in the BAL observed in the current experiment has not previously been reported, although other lymphocyte subsets have been changed following $\mathrm{NO}_{2}$ exposure [20-25]. The Bcell, T-suppressor, and NK subsets were not-changed in the current experiment and have been variably changed in 
Table 5. - Total protein (TP) and lactate dehydrogenase (LDH) in bronchial fraction (BFx) and bronchoalveolar lavage (BAL), post-exposure to filtered air (FA) and nitrogen dioxide $\left(\mathrm{NO}_{2}\right)$

\begin{tabular}{|c|c|c|c|c|}
\hline & \multicolumn{2}{|c|}{$\mathrm{BFx}$} & \multicolumn{2}{|c|}{ BAL } \\
\hline & FA & $\mathrm{NO}_{2}$ & FA & $\mathrm{NO}_{2}$ \\
\hline $\mathrm{TP} \mathrm{mg} \cdot \mathrm{mL}^{-1}$ & 0.171 & $0.117 *$ & 0.114 & 0.105 \\
\hline IQR & $0.124-0.232$ & $0.099-0.189$ & $0.086-0.134$ & $0.066-0.144$ \\
\hline $95 \%$ CI & $0.136-0.258$ & $0.102-0.161$ & $0.094-0.146$ & $0.079-0.165$ \\
\hline LDH mL & 14.2 & 9.3 & 8.6 & 6.9 \\
\hline IQR & $9.3-19.7$ & $5.0-16.7$ & $4.2-15.6$ & $5.8-9.8$ \\
\hline $95 \% \mathrm{CI}$ & $10.5-16.9$ & $6.3-14.4$ & $5.6-16.9$ & $6.0-11.4$ \\
\hline
\end{tabular}

Values are median and interquartile range (IQR). 95\% CI: 95\% confidence interval. *: significantly different from filtered air ( $\mathrm{p}=0.004)$.

other experiments [20-25]. Taken together, the results of controlled human $\mathrm{NO}_{2}$ exposure experiments show no consistent effect on a specific lymphocyte subset or group of subsets over a range of $\mathrm{NO}_{2}$ exposure conditions. Although it is not known if different lymphocyte subsets have different specific sensitivities or responses to $\mathrm{NO}_{2}$ exposure, it is probable that any oxidative or free-radical effects of $\mathrm{NO}_{2}$, would be similar across all lymphocyte subsets, given the similarities in cell structure. The T-suppressor/T-helper cell ratio may be an important variable as an indication of cellular immune function. The decrease in T-helper cells did not result in any significant change in this ratio, suggesting that the current $\mathrm{NO}_{2}$ exposure did not result in a functional change in cellular immunity. This is also apparent by the lack of change in activation of any of the lymphocyte subsets following $\mathrm{NO}_{2}$ exposure. This finding could indicate a different response following multiple day exposure, compared to the increase in T-cell activation following a single exposure [21].

The finding in this experiment of only a small decrease in one cell population involved in cellular immune responses may help to explain why no $\mathrm{NO}_{2}$-induced changes in response to experimental infection have been found in controlled human exposure experiments [38, 39]. The finding of no change in any of the leukocyte or lymphocyte subsets in the $\mathrm{PB}$ indicates that the inhaled $\mathrm{NO}_{2}$ or a reaction product were either not transferred to the blood, or that the concentration of these molecules was too low to have an effect on the measured variables. This finding could be a function of a different response following multiple day exposure, compared to the increase in total lymphocytes, and the decrease in T-cells in blood following single exposures $[21,24,25]$.

The findings of increased neutrophils and decreased total protein in the BFx, but not in the BAL, suggest regional differences in the response to inhaled $\mathrm{NO}_{2}$. This differential response may be due to differences in $\mathrm{NO}_{2}$ exposure (delivery), absorbance, clearance, or antioxidant defenses. Therefore it would be informative to include analysis of lymphocyte subsets in the BFx in future experiments. The decrease in total protein in the BFx may be due a decrease in epithelial permeability that has been demonstrated following $\mathrm{NO}_{2}$ exposure [34]. It would appear that $\mathrm{NO}_{2}$ decreases the transfer of proteins to the extracellular space, which could effect cellular function.

In conclusion, exposure to nitrogen dioxide under the conditions used in the current experiment resulted in an increase in neutrophils in the bronchial fraction and a decrease in T-helper cells in the bronchoalveolar lavage. The changes observed in the measured variables indicate that serial-day exposure to a high-ambient level of nitrogen dioxide is unlikely to produce any associated immunopathology. However, it cannot be excluded that higher concentrations ( $>2.0$ parts per million), chronic exposure ( $>3$ days), or exposure of specifically responsive individuals could result in larger nitrogen dioxide-induced changes in airway inflammation and cellular immunity.

\section{References}

1. Spedding DJ. Air pollution. Oxford chemistry series. Oxford, UK, Clarendon Press, 1974; pp. 76-82.

2. Goldstein IF, Lieber K, Andrews LR, et al. Acute respiratory effects of short-term exposures to nitrogen dioxide. Arch Environ Health 1988; 43: 138-142.

3. Norman $\mathrm{V}$, Keith $\mathrm{CH}$. Nitrogen oxides in tobacco smoke. Nature 1965; 205: 915-916.

4. United States Environmental Protection Agency: Office of Planning and Standards. National air pollution emissions estimates 1940-1990. Research Triangle Park. 1991; 450/491/026.

5. Hedberg K, Hedberg CW, Iber C, et al. An outbreak of nitrogen dioxide-induced respiratory illness among ice hockey players. JAMA 1989; 262: 3014-3017.

6. Spengler J, Ryan PB, Schwab M, et al. An overview of the Los Angeles personal monitoring study. Total Exposure Assessment Methodology. Proc EPA/Air Waste Manage Assoc 1990; 66-85.

7. Sexton K, Letz R, Spengler JD. Estimating human exposure to nitrogen dioxide: an indoor/outdoor modeling approach. Environ Res 1983; 32: 151-166.

8. Mohsenin V. Human exposure to oxides of nitrogen at ambient and supra-ambient concentrations. Toxicology 1994; 89: 301-312.

9. Speizer FE, Ferris BG Jr. Exposure to automobile exhaust. I. Prevalence of respiratory symptoms and disease. Arch Environ Health 1973; 26: 313-324.

10. Helsing KJ, Comstock GW, Meyer MB, Tockman ML. Respiratory effects of household exposures to tobacco smoke and gas cooking on non-smokers. Environ Int 1982; 8: 365-370.

11. Detels R, Sayre JW, Coulson AH, et al. The UCLA population studies of chronic obstructive respiratory disease. IV. Respiratory effects of long-term exposure to photochemical oxidants, nitrogen dioxide, and sulfates on current and never smokers. Am Rev Respir Dis 1981; 124 : 673-680.

12. Yokoyama Y, Nitta H, Maeda K, Aoki S. What interaction does indoor nitrogen dioxide have on the effect of the 
automobile exhaust. Tokai J Exp Clin Med 1985; 10: 379_ 384.

13. Koo LC, Ho JH, Ho CY, Matsuki H, Shimizu H, Mori T. Personal exposure to nitrogen dioxide and its association with respiratory illness in Hong Kong. Am Rev Respir Dis 1990: 141: 1119-1126.

14. Cohen CA, Hudson AR, Clausen JL, Knelson JH. Respiratory symptoms, spirometry, and oxidant air pollution in nonsmoking adults. Am Rev Respir Dis 1972; 105: 251-261.

15. Keller MD, Lanese RR, Mitchell RI, Cote RW. Respiratory illness in households using gas and electricity for cooking. I. Survey of incidence. Environ Res 1979; 19: 495-503.

16. Euler GL, Abbey DE, Hodgkin JE, Magie AR. Chronic obstructive pulmonary disease symptom effects of longterm cumulative exposure to ambient levels of total oxidants and nitrogen dioxide in California Seventh-day Adventist residents. Arch Environ Health 1988; 43: 279_ 285.

17. Hasselbad V, Kotchmar DJ, Eddy DM. Synthesis of environmental evidence: nitrogen dioxide epidemiology studies. J Air Waste Manage Assoc 1992; 42: 662-671.

18. Sandstrom T, Andersson MC, Kolmodin-Hedman B, Stjernberg N, Angstrom T. Bronchoalveolar mastocytosis and lymphocytosis after nitrogen dioxide exposure in man: a time-kinetic study. Eur Respir J 1990; 3: 138-143.

19. Sandstrom T, Stjernberg N, Eklund A, et al. Inflammatory cell response in bronchoalveolar lavage fluid after nitrogen dioxide exposure of healthy subjects: a dose-response study. Eur Respir J 1991; 3: 332-339.

20. Helleday R, Sandstrom T, Stjemberg N. Differences in bronchoalveolar cell response to nitrogen dioxide exposure between smokers and nonsmokers. Eur Respir $J$ 1994; 7: 1213-1220.

21. Blomberg A, Krishna MT, Bocchino V, et al. The inflammatory effects of $2 \mathrm{ppm} \mathrm{NO}_{2}$ on the airways of healthy subjects. Am J Respir Crit Care Med 1997; 156: 418-424.

22. Azadniv M, Utell MJ, Morrow PE, et al. Effects of nitrogen dioxide exposure on human host defense. Inhal Toxicol 1998; 10: 585-601.

23. Rubenstein I, Reiss TF, Bigby BG, Stites DP, Boushey HA Jr. Effects of $0.60 \mathrm{ppm}$ nitrogen dioxide on circulating and bronchoalveolar lavage lymphocyte phenotypes in healthy subjects. Environ Res 1991; 55: 18-30.

24. Sandstrom T, Ledin M-C, Thomasson L, Helleday R, Stjernberg N. Reductions in lymphocyte subpopulations after repeated exposure to $1.5 \mathrm{ppm}$ nitrogen dioxide. $\mathrm{Br} J$ Ind Med 1992; 49: 850-854.

25. Sandstrom T, Helleday R, Bjermer L, Stjernberg N. Effects of repeated exposure to $4.0 \mathrm{ppm}$ nitrogen dioxide on bronchoalveolar lymphocyte subsets and macrophages in healthy men. Eur Respir J 1992; 5: 1092-1096.

26. Blomberg A, Krishna MT, Helleday R, et al. Persistant airway inflammation but accommodated antioxidant and lung function responses after repeated daily exposure to nitrogen dioxide. Am J Respir Crit Care Med 1999; 159 : 536-543.

27. Cebrian M, Yague E, Rincon M, Lopez-Botet M, de Landazuri MO, Sanchez-Madrid F. Triggering of T cell proliferation through AIM, an activation inducer molecule expressed on activated human lymphocytes. $J$ Exp Med 1988; 168: 1621-1637.

28. Walker C, Bode E, Boer L, Hansel TT, Blaser K, Virchow JC Jr. Allergic and nonallergic asthmatics have distinct patterns of T-cell activation and cytokine production in peripheral blood and bronchoalveolar lavage. Am Rev Respir Dis 1992; 146: 109-115.

29. Ancochea J, Gonzalez A, Sanchez MJ, Aspa J, LopezBotet M. Expression of lymphocyte activation surface antigens in bronchoalveolar lavage and peripheral blood cells from young healthy subjects. Chest $1993 ; 104$ : 32-37.

30. Menzel DB. The role of free radicals in the toxicity of air pollutants (nitrogen oxides and ozone). In: Pryor WA ed. Free radicals in biology: Vol. II. New York, Academic Press, 1976; pp. 181-202.

31. Mohsenin V, Gee BL. Acute effect of nitrogen dioxide exposure on the functional activity of alpha-1-protease inhibitor in bronchoalveolar lavage fluid of normal subjects. Am Rev Respir Dis 1987; 136: 646-650.

32. Frampton MW, Finkelstein JN, Roberts NJ Jr, Smeglin AM, Morrow PE, Utell MJ. Effects of nitrogen dioxide exposure on bronchoalveolar lavage proteins in humans. Am J Respir Cell Mol Biol 1989; 1: 499-505.

33. Kelly FJ, Blomberg A, Frew A, Holgate ST, Sandstrom T. Antioxidant kinetics in lung lavage fluid following exposure of humans to nitrogen dioxide. Am J Respir Crit Care Med 1996; 154: 1700-1705.

34. Rasmussen TR, Kjaergaard SK, Tarp U, Pederson OF. Delayed effects of $\mathrm{NO}_{2}$ exposure on alveolar permeability and glutathione peroxidase in healthy humans. Am Rev Respir Dis 1992; 146: 654-659.

35. American Thoracic Society. Standardization of Spirometry, 1994 Update. Am J Respir Crit Care Med 1995; 152: $1107-1136$.

36. Kanner RE, Connett JE, Altose MD, et al. Gender difference in airway hyperresponsiveness in smokers with mild COPD. The lung health study. Am J Respir Crit Care Med 1994; 150: 956-961.

37. Markwell MA, Haas SM, Bieber LL, Tolbert NE. A modification of the Lowry procedure to simplify protein determination in membrane and lipoprotein samples. Anal Biochem 1978; 87: 206-210.

38. Frampton MW, Smeglin AM, Roberts NJ Jr, Finkelstein JN, Morrow PE, Utell MJ. Nitrogen dioxide exposure in vivo and human alveolar macrophage inactivation of influenza virus in vitro. Environ Res 1989; 48: 179-192.

39. Goings SA, Kulle TJ, Bascom R, etal. Effect of nitrogen dioxide exposure on susceptibility to influenza A virus infection in healthy adults. Am Rev Respir Dis 1989; 139: 1075-1081. 